\title{
Prinsip-Prinsip Human Relations dalam Pelaksanaan Komunikasi Organisasi di Kementerian Komunikasi dan Informatika
}

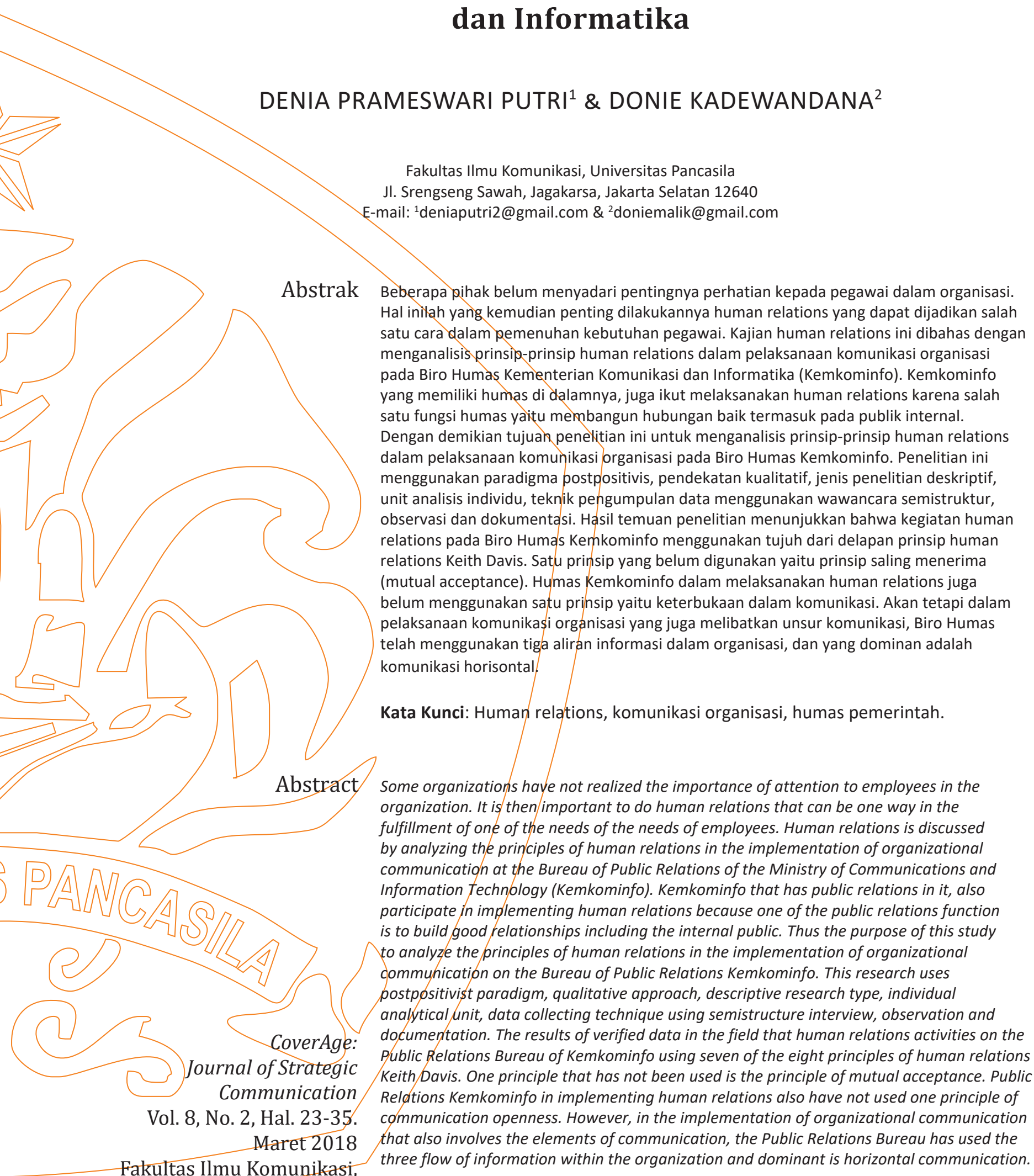

Universitas Pancasila

Keywords: Strip comic, social critic, virtual communities

Diterima 15 November 2017

Disetujui 9 Februari 2018 


\section{PENDAHULUAN}

Suatu organisasi dapat dipandang efektif ketika organisasi mampu memenuhi kebutuhan dari dua hal, yaitu pegawai dan organisasi. Pemenuhan akan kedua kebutuhan tersebut penting dilakukan karena juga memengaruhi kelangsungan organisasi. Hal itu seperti dikutip Chung \& Leon (1981: 31) bahwa kelangsungan organisasi tergantung pada besarnya kemampuan untuk memuaskan kedua tujuan yaitu tujuan individu dan organisasi. Namun, pada praktiknya, organisasi belum mampu memenuhi salah satu kebutuhan yaitu kebutuhan pegawai.

TinyPulse melakukan survei mengenai pekerjaan pegawai di Asia Pasifik. Survei mengatakan bahwa hanya sepertiga dari pegawai di Asia Pasifik yang senang dengan pekerjaan mereka. Sisanya terkadang mengalami kegelisahan dengan bidang pekerjaan, masalah hubungan atasan-bawahan dan yang terbesar adalah masalah komunikasi internal. Hampir $40 \%$ pegawai di Asia memiliki masalah interaksi dengan atasan mereka. Ini lebih tinggi dari rata-rata global, yang hanya sekitar $15 \%$ (https.ekbis. sindonews.com).

Pemenuhan akan kebutuhan pegawai penting dilakukan dalam organisasi salah satunya dengan memberikan perhatian pada pegawai. Pentingnya perhatian pada pegawai karena sebagaimana dikatakan Nurdin (2009) bahwa pegawai merupakan ujung tombak organisasi harus diperhatikan keberadaannya karena dapat menentukan keberhasilan dari tujuan organisasi.

Komunikasi pegawai perlu dilakukan karena ketika adanya kegagalan yang serius dalam komunikasi tersebut, dapat menciptakan kelambanan pegawai, ketidakefisienan, semangat kerja menurun, produktivitas dan disiplin kerja pegawai menurun. Jika hal itu terjadi, dampak buruk pun juga bisa terjadi baik yang berkaitan dengan tujuan maupun stakeholder dalam organisasi tersebut (Ardianto, 2013: 100).

Pada komunikasi pegawai yang dilakukan dalam organisasi, akan lebih baik ketika mengandung unsur persuasi. Inilah yang kemudian dapat dilakukannya human relations sebagai suatu interaksi yang mengandung teknik-teknik persuasi di dalamnya dan penting dilakukan terutama jika adanya humas dalam organisasi tersebut.

Pentingnya human relations karena terkadang sikap, keyakinan, perilaku dan perbuatan yang dilakukan di organisasi menimbulkan berbagai masalah hubungan. Masalah hubungan dapat terjadi baik yang berkaitan dengan kehidupan pribadi maupun pekerjaan. Oleh karena itu, human relations diperlukan agar hubungan yang dijalin tetap harmonis dan masalah lain juga dapat dicegah.

Dalam organisasi, termasuk organisasi pemerintah, tidak terlepas dari berbagai permasalahan seperti masalah internal. Munculnya masalah internal karena di organisasi terdiri atas berbagai orang dari latar belakang budaya, ras, maupun agama berbeda yang saling terikat satu sama lain dalam suatu sistem organisasi. Di sinilah dapat muncul berbagai masalah dalam organisasi.

Lengkey (2015) mengatakan bahwa masalah internal yang dapat muncul seperti kurangnya komunikasi secara lisan, di mana pegawai merasa canggung untuk menyampaikan pertanyaan, saran maupun kritikan pada pimpinan, kurangnya interaksi sesama pegawai sehingga sering terjadi salah pengertian dalam koordinasi tugas dan penyampaian informasi, sikap kerja sama yang belum optimal dengan membebankan pekerjaan yang kepada pegawai lain dan lainnya.

Permasalahan internal organisasi juga dialami Kementerian Komunikasi dan Informatika (Kemkominfo). Sebagai salah satu lembaga pemerintahan yang menyelenggarakan urusan di bidang komunikasi dan informatika, Kemkominfo memiliki masalah salah satunya terkait dengan pegawai Biro Hubungan Masyarakat (Biro Humas). Masalah tersebut pertama yaitu tumpang tindih pekerjaan yang terkadang dilakukan pegawai terhadap pegawai lain terutama yang biasanya memiliki jabatan lebih tinggi dibandingkan pegawai lain. Tumpang tindih pekerjaan pun juga terkadang dilakukan oleh beberapa pegawai yang sudah bekerja lama di Kemkominfo kepada para pegawai baru Kemkominfo.

Kedua, kesadaran bekerja secara maksimal juga masih kurang. Hal itu terlihat dari kurangnya disiplin pegawai dalam melakukan pekerjaan. Kurangnya disiplin terjadi salah satunya ketika pekerjaan yang ditugaskan seringkali tidak selesai tepat waktu. Selain itu, kurangnya kesadaran bekerja juga terlihat dari kurangnya kesadaran akan tugas dan tanggung jawab yang harus dilakukan sebagai pegawai dalam bekerja.

Ketiga, kurangnya semangat kerja yang terlihat dari masih adanya pegawai yang tidur saat jam kerja, hasil pekerjaan yang tidak maksimal, tidak mampu melaksanakan apa yang telah sesuai dengan rencana kerja (SOP) dan kurang adanya kepuasan terhadap hasil kerja maupun motivasi dalam bekerja oleh 
beberapa pegawai Biro Humas Kemkominfo.

Keempat masalah hubungan. Masalah hubungan juga kadang terjadi pada pegawai Biro Humas. Masalah hubungan terjadi ketika adanya satu atau beberapa pegawai yang tidak suka terhadap pegawai lain. Hal tersebut seringkali karena sikap maupun perilaku pegawai yang menimbulkan ketidaksukaan pegawai lain misalnya tidak ada saat jam kerja, tidak dilakukannya pekerjaan yang telah ditugaskan, kebiasaan dalam membicarakan keburukan orang lain dan lain sebagainya.

Masalah hubungan yang terjadi juga dapat dikatakan karena kurangnya keterbukaan satu sama lain di antara pegawai dan juga komunikasi yang dilakukan sehingga masalah hubungan ini yang kemudian menjadi suatu konflik internal dalam Biro Humas. Ketika konflik internal terjadi, maka nantinya dapat berpengaruh terhadap pekerjaan yang dilakukan para pegawai, kinerjanya dan hubungan kerja yang terjalin.

Melihat masih adanya berbagai masalah internal pada Biro Humas, kemudian menjadi tantangan bagi humas Kemkominfo karena selain menciptakan hubungan yang harmonis, humas juga harus mampu menjadi pendengar yang baik dan perantara komunikasi. Hal tersebut seperti dikutip Cutlip, et al (2006: 47) bahwa salah satu fungsi pokok humas yaitu sebagai fasilitator komunikasi antara organisasi dengan publiknya termasuk publik internal yaitu pegawai.

Jika fungsi humas dilaksanakan dengan baik, sebenarnya dapat menjadi alat terbaik untuk memperbaiki, mengembangkan peraturan, suasana kerja yang kondusif, peka terhadap pegawai yang perlu pendekatan khusus, perlu dimotivasi dalam meningkatkan kinerjanya, dan lainnya (Rumanti, 2005: 34). Jika hal itu sudah dilakukan, maka hubungan kerja, kerja sama, kepercayaan antara organisasi dengan pegawainya, dan kebutuhan pegawai dapat terpenuhi dan pegawai pun juga akan merasa puas.

Humas juga menyadari bahwa komunikasi yang baik serta hubungan manusiawi yang benarbenar manusiawi merupakan alat dalam mengatasi masalah hubungan ataupun sampai terjadi konflik. Atas dasar itu, di sinilah pentingnya human relations oleh humas Kemkominfo melalui prinsip-prinsip human relations dalam pelaksanaan komunikasi organisasi.

Dengan demikian, peneliti tertarik untuk mengetahui apakah human relations yang dilakukan humas Kemkominfo dalam pelaksanaan komunikasi organisasi sudah berdasarkan prinsip-prinsip human relations yang ada melalui analisis prinsip-prinsip human relations. Oleh karena itu, tujuan penelitian ini adalah untuk mengetahui penerapan prinsip-prinsip human relations dalam pelaksanaan komunikasi organisasi pada Biro Humas Kemkominfo?

\section{TINJAUAN PUSTAKA}

\section{Human Relations dalam Organisasi}

Dalam organisasi ketika kebutuhan para pekerja dapat terpenuhi, maka organisasi tersebut dapat efektif. Dalam hal ini, pekerja dianggap termotivasi terutama oleh keinginan dan kepuasan kerja, pengakuan, perhatian dan pengambilan keputusan (Ruben \& Stewart, 2006: 300). Inilah pentingnya pelaksanaan human relations untuk kepuasan bersama kedua belah pihak melalui interaksi-interaksi yang dilakukan dalam organisasi.

Istilah human relations sebenarnya sulit untuk menemukan arti terjemahannya. Effendy (2009: 41) dalam bukunya mengatakan bahwa ada yang menerjemahkan menjadi "hubungan manusia" tetapi ada juga yang menerjemahkannya menjadi "hubungan antar manusia." Sebenarnya tidak ada ciri khas baik dari istilah hubungan manusia ataupun hubungan antar manusia karena makna sebenarnya berfokus pada kebahagiaan berdasarkan watak, sifat, kepribadian, sikap, tingkah laku dan aspek kejiwaan dalam diri manusia.

Keith Davis (1957: 4) mengemukakan mengenai istilah human relations secara luas yaitu interaksi orang-orang di semua jenis usaha, mulai dari bisnis, politik, di rumah dan di sekolah. Berdasarkan hal tersebut maka human relations dapat dilakukan di segala tempat termasuk organisasi. Ketika human relations dilakukan di organisasi, maka fokusnya lebih pada hubungan kerja yang erat untuk pencapaian tujuan organisasi.

Keith Davis juga mengemukakan mengenai tiga tujuan penting human relations yaitu untuk bekerjasama, untuk menghasilkan dan mendapat kepuasan dari pekerjaan mereka (Davis, 1957: 4). Ketika tujuan itu dapat diraih maka hasilnya yaitu kesuksesan maupun keberhasilan suatu organisasi. Kerja sama oleh kelompok orang dalam organisasi serta adanya motivasi sangat dibutuhkan dalam pemenuhan tujuan tersebut. 


\section{a. Human Relations}

Ada berbagai definisi mengenai human relations menurut para ahli di antaranya Ruslan, Effendy dan Davis. Ruslan (2016: 87) mengemukakan dua definisi human relations dalam arti luas dan sempit yaitu:

1. Human relations dalam arti luas adalah interaksi antara seseorang dengan orang atau kelompok lain yang menyangkut hubungan manusiawi, etika atau moral, aktivitas sehari-hari yang pada umumnya bertujuan untuk memeroleh kepuasan bagi kedua belah pihak.

2. Human relations dalam arti sempit yaitu terjadinya suatu interaksi antara seseorang dan orang atau kelompok lainnya. Interaksi yang terjadi misalnya dalam hubungan pekerjaaan dan organisasi kekaryaan. Tujuannya adalah memotivasi semangat pekerja dalam melaksanakan pekerjaan, menciptakan kepuasan kerja, sense of belonging (rasa memiliki) yang dikaitkan dengan peningkatan produktivitas perusahaan.

\section{b. Prinsip-Prinsip Human Relations}

Selanjutnya dalam menjalin hubungan dengan manusia, ada beberapa prinsip-prinsip yang harus dipegang untuk mengembangkan human relations yang lebih baik. Prinsip-prinsip ini dikemukakan oleh Keith Davis (1957: 28-29). Ada delapan prinsip dalam mengembangkan human relations yang lebih baik. Prinsip-prinsip tersebut terdiri atas:

1. Kepentingan Individu (Importance of Individual)

Prinsip ini menjelaskan bahwa kepentingan individu harus diperhatikan pada setiap pegawai dan mengenali perasaannya masing-masing. Selain itu memastikan perlakuan masing-masing orang sebagai individu, pegawai, pekerja dan sebagainya juga penting dilakukan agar semangat kerja dapat meningkat dan kinerja juga dapat memuaskan.

Davis \& Scott dalam buku yang berjudul Reading in Human relations (1959: 60) juga menyebutkan bahwa setiap pegawai harus dibantu untuk merasakan pekerjaannya, tidak peduli seberapa kecil bagiannya dari seluruh proses yang ada. Hal tersebut agar semangat kerjanya juga dapat meningkat. Lalu, pegawai juga harus tergabung dalam suatu kelompok, untuk merasakan bahwa mereka merupakan bagian dari tim kerja. Setiap atasan atau manajemen pun sebaiknya mengetahui para pegawainya secara personal, mencoba untuk membantu menyelesaikan masalah mereka, dan memahami jika ada pegawai yang secara alami menolak perubahan yang mereka tidak mengerti.

2. Saling Menerima (Mutual Acceptance)

Prinsip ini menjelaskan bahwa pegawai, serikat pekerja dan manajemen atau atasan perlu adanya sikap saling menerima sebagai individu dan kelompok serta kebutuhan untuk saling menghormati fungsi dan tanggung jawab masing-masing. Memahami antara pimpinan dan bawahan juga diperlukan dalam melakukan berbagai tugas yang diberikan.

Di sisi lain, Raelin (2002: 112) menjelaskan bahwa sikap saling menerima terjadi ketika individu secara formal dan informal diberikan keanggotaan dalam organisasi dan menandakan kecocokan antara kebutuhan pribadi dan kebutuhan organisasi. Dari adanya sikap saling menerima individu juga dapat terus menjalani kehidupan yang produktif, memuaskan dan bahkan kehidupan permanen dalam organisasi atau sebaliknya, dapat meninggalkan organisasi karena berbagai alasan, termasuk kegagalan dari sikap saling menerima.

3. Kepentingan Bersama (Common Interest)

Prinsip ini menjelaskan bahwa pegawai, serikat pekerja dan manajemen saling terikat satu sama lain dari kepentingan bersama. Adanya keterikatan ini untuk terciptanya tujuan organisasi yang dilakukan secara bersama melalui kerja sama seluruh komponen organisasi. Indrawijaya (2010: 100) juga mengemukakan bahwa kerjasama sering dianggap sebagai tujuan dari suatu sistem organisasi. Kerja sama yang dilakukan karena adanya kepentingan bersama juga dapat memberikan keuntungan bagi organisasi dan pengaruh baik bagi perilaku anggotanya.

Selanjutnya kepentingan bersama yang dilakukan melalui kerja sama dapat meningkatkan produktivitas dan dapat menciptakan keselarasan hubungan antar manusia, kelompok dan lain sebagainya. Oleh karena itu, ketika kepentingan bersama berhasil dilakukan, maka keamanan individu dan kemampuan mereka dalam bekerja juga dapat dikatakan sukses.

4. Keterbukaan Komunikasi (Open Communication)

Prinsip ini menjelaskan bahwa berbagi gagasan, informasi dan perasaan dengan seluruh komponen organisasi sangat penting sebagai jalan menuju pemahaman dan keputusan yang lebih baik. Komunikasi terbuka juga 
penting dilakukan untuk memperoleh saling pengertian maupun pelaksanaan tugas secara efektif dan lain sebagainya. Davis (1957: 229) juga mengemukakan bahwa ketika komunikasi terbuka tidak dilakukan, maka hasilnya dapat meliputi kesalahpahaman, kurangnya motivasi, ketidakamanan, konflik, dan ketidakmampuan membuat keputusan yang efektif.

5. Partisipasi Pegawai (Employee Participations)

Prinsip ini menjelaskan bahwa hasil yang lebih baik dapat terjadi melalui adanya keseimbangan dalam melihat sudut pandang orang-orang di semua tingkatan di organisasi. Lalu adanya sikap saling berbagi serta pemecahan masalah dari orang-orang yang terpengaruh. Partisipasi pegawai juga dilakukan dengan melibatkan partisipan dalam menyampaikan pendapat, ide, maupun saran bagi semua komponen dalam organisasi.

Davis (1957: 294) menyebutkan beberapa keuntungan adanya partisipasi pegawai di antaranya mendorong keputusan yang lebih baik, menggunakan kreativitas seluruh pegawai, mengembalikan ukuran dari harga diri, motivasi dan kepentingan bersama yang saling menguntungkan, mendorong orang-orang menerima tanggung jawabnya, mengembangkan moral dan kerjasama dan mendorong dalam menerima perubahan.

Davis dalam bukunya yang berjudul Human Behavior at Work: Human Relations and Organizational Behavior (1972: 136) menyebutkan partisipasi melibatkan mental dan emosional, bukan pada aktivitas otot. Pada partisipasi, diri seseorang terlibat, bukan hanya keahliannya jadi keterlibatan lebih kepada psikologis bukan fisiknya. Partisipasi terjadi ketika ada pegawai yang termotivasi untuk berkontribusi dalam suatu situasi. Pegawai diberi kesempatan untuk berinisiatif dan mengembangkan kreativitas mereka sendiri untuk mencapai tujuan organisasi.

Partisipasi lebih dari sekedar menyetujui sesuatu yang sudah diputuskan. Ini adalah hubungan psikologis dan hubungan sosial dua arah di antara orang-orang daripada prosedur untuk memaksakan gagasan dari atasan atau pimpinan. Partisipasi juga berarti mendorong pegawai untuk menerima tanggung jawabnya dalam aktivitas kelompok. Hal tersebut merupakan proses sosial di mana seseorang menjadi dirinya sendiri, terlibat dalam organisasi dan ingin melihat kesuksesan kerja.

6. Identitas Lokal (Local Identity)

Prinsip ini menjelaskan bahwa individu dapat menerima kesempatan terbesar untuk pengakuan, kebanggaan dan kepuasan kerja melalui identifikasi dengan unit kerja lokalnya. Quick \& Debra (2013: 112) juga mengemukakan bahwa adanya kesempatan-kesempatan seperti kepuasan kerja ini bisa didapat melalui adanya perlakuan baik dan kepuasan yang dapat terdiri atas gaji, pekerjaan itu sendiri, kesempatan promosi dan lain sebagainya.

Robbins (2006: 32) pun mengemukakan bahwa kepuasan kerja lebih mencerminkan sikap daripada perilaku dan dapat dianggap sebagai tujuan resmi organisasi. Hal tersebut tentunya dapat dilakukan dengan mengidentifikasi unit kerja lokalnya.

7. Keputusan Lokal (Local Decisions)

Prinsip ini menjelaskan bahwa orangorang yang paling dekat dengan masalah yang memengaruhi diri mereka sendiri dapat mengembangkan solusi yang paling memuaskan jika diberi wewenang untuk menyelesaikan masalah tersebut. Jadi, jika ada masalah yang terjadi pada diri mereka, ketika diberikan wewenang untuk menyelesaikannya, maka mereka sebenarnya dapat menyelesaikan masalah tersebut dengan solusi-solusi yang juga dapat memuaskan.

8. Standar Moral yang Tinggi (High Moral Standard)

Prinsip ini menjelaskan bahwa dasar yang paling tepat untuk menilai "kebenaran" sebuah tindakan yang melibatkan orang-orang adalah ujian moralitas dan itu berpengaruh pada hak asasi manusia. Standar moral yang tinggi juga harus diperhatikan pada setiap tindakan, sikap ataupun perilaku sebagai profesional, pimpinan dan pekerja.

Para profesional, pimpinan dan pekerja dengan moral tinggi menyukai pekerjaan dan organisasi mereka dan berkeinginan untuk bekerja sama dengan pegawai lain untuk pencapaian tujuan bersama. Moral yang tinggi juga merupakan ciri khas human relations yang baik dalam organisasi.

Davis (1957: 445) menambahkan bahwa moral penting karena merepresentasikan kondisi umum dari human relations. Moral termasuk dalam rangkaian sikap pegawai, perasaan, dan 
kepekaan perasaan itu sendiri dan untuk melihat moral secara khusus, seseorang harus melihat sikap ini dalam kaitannya dengan kelompok tertentu dan kondisi organisasi tertentu.

Meskipun moral terdiri dari sejumlah sikap terpisah yang tidak terbatas pada setiap orang, ada beberapa kesepakatan mengenai area di mana kepuasan pegawai diperlukan agar memiliki moral yang tinggi. Area itu disebut faktor moral yang terdiri atas kecukupan pengawasan langsung, kepuasan dengan pekerjaan itu sendiri, kompatibilitas dengan sesama pegawai, tujuan dan efektifitas organisasi yang memuaskan sebagai sebuah sistem, kepuasan yang terkait dengan imbalan dan penghargaan serta kesehatan fisik dan mental umum.

Berdasarkan penjelasan di atas diharapkan tujuan organisasi dapat tercapai dari adanya hubungan kerja yang harmonis, peningkatan semangat kerja dan motivasi kerja sehingga produktivitas dan disiplin pegawai juga dapat meningkat.

Prinsip-prinsip dalam human relations memiliki asumsi menarik. Miller (2012: 45) mengemukakan bahwa ketika memiliki asumsi baik tentang pegawai yaitu memperlakukan mereka dengan baik diperkaya dengan pekerjaan yang menantang dan memenuhi kebutuhan mereka untuk harga diri serta aktualisasi diri, maka bisa menghasilkan iklim di mana kepuasan pekerja dan produktivitas akan berkembang.

\section{Komunikasi Organisasi}

Ada beberapa definisi mengenai komunikasi organisasi menurut berbagai ahli. Keyton (2005:13) mendefinisikan komunikasi organisasi adalah proses yang bersifat kompleks dan berkesinambungan di mana anggota organisasi menciptakan, memelihara dan mengubah organisasi.

Goldhaber seperti dikutip Muhammad (2008: 67) mendefinisikan komunikasi organisasi sebagai proses menciptakan dan saling menukar pesan dalam satu jaringan hubungan yang saling tergantung satu sama lain untuk mengatasi lingkungan yang tidak pasti atau selalu berubah.

Berdasarkan definisi di atas dirumuskan bahwa pada komunikasi organisasi ada pesan yang disampaikan dan diterima dalam suatu jaringan organisasi untuk mengatasi ketika ada kondisi yang berubah dalam organisasi dan lainnya. Selain itu, seluruh anggota organisasi pun berpartisipasi dalam proses ini untuk keberhasilan dan tercapainya tujuan organisasi.

Sebagaimana dikemukakan oleh Redding dan Sanborn sebelumnya bahwa komunikasi organisasi terdiri atas adanya komunikasi upward dan downward, maka suatu organisasi tidak terlepas dari adanya aliran informasi dalam penyampaian suatu informasi. Aliran informasi ini juga yang berkaitan dengan jaringan komunikasi yang ada dalam organisasi yaitu jaringan komunikasi formal dan informal.

\section{Humas Pemerintah}

Mengacu pada Peraturan Menteri Pendayagunaan Aparatur Negara Nomor: 12/Kep/M.Pan/08/Tahun 2007 tentang Pedoman Umum Hubungan Masyarakat di Lingkungan Instansi Pemerintah, Humas Pemerintah adalah aktivitas lembaga atau individu yang melakukan fungsi manajemen dalam bidang komunikasi dan informasi kepada publik pemangku kepentingan dan juga sebaliknya (Sangadji, 2007: 24). Aktivitas ini dilakukan humas pada publiknya baik internal maupun eksternal untuk pencapaian tujuan organisasi melalui penyampaian komunikasi dan interaksi di dalamnya.

Komarudin (2014: 12) menyebutkan ada ruang lingkup humas pemerintah meliputi:

1. Kegiatan yang dilaksanakan humas pemerintah secara timbal balik dengan pemangku kepentingan melalui berbagai bentuk penyampaian pesan dan penciptaan opini publik.

2. Komunikasi positif internal dan eksternal yang terencana untuk menciptakan saling pengertian dalam mencapai tujuan tertentu dan memeroleh manfaat bersama bagi lembaga dan pemangku kepentingan.

3. Kegiatan yang melaksanakan fungsi manajemen pemerintahan.

4. Aktivitas dalam rangka membangun citra dan reputasi organisasi, pemerintah, bangsa dan negara.

Berdasarkan penjelasan di atas dirumuskan bahwa ada berbagai kegiatan dan aktivitas yang dilakukan humas pemerintah khususnya melalui komunikasi, baik kepada publik internal maupun eksternal organisasi untuk mencapai tujuan yang diinginkan organisasi dan manfaat pada kedua belah pihak. Manfaat kedua belah pihak inilah yang dapat menguntungkan satu sama lain dalam kegiatan tersebut. 


\section{METODE}

Penelitian ini menggunakan pendekatan kualitatif, dengan jenis penelitian yang akan digunakan yaitu jenis penelitian deskriptif. Penelitian deskriptif ini melihat bagaimana human relations yang dilakukan humas Kemkominfo dan mendeskripsikan dari prinsip-prinsip human relations yang ada apakah dapat mempererat hubungan kerja antar pegawai Biro Humas Kemkominfo, memperbaiki, menciptakan suasana kerja yang kondusif, memotivasi pegawainya dalam meningkatkan kinerjanya, dan lain sebagainya. Hal tersebut kemudian dideskripsikan secara rinci dalam penelitian ini berdasarkan situasi dan keterlibatan komponen yang ada pada Biro Humas Kemkominfo.

Pada penelitian ini menggunakan teknik pengumpulan data primer melalui wawancara mendalam dengan key informan dan informan terpilih untuk memberikan informasi yang dibutuhkan dalam penelitian. Wawancara dilakukan dengan dua informan terkait yaitu humas Kemkominfo. Pertama adalah Nooriza yang merupakan PIt Kepala Biro Humas Kemkominfo dan Teguh Wahyono merupakan Kepala Subbagian Pengelolaan Opini Publik dan Analisa Berita di Biro Humas. Pada sumber data sekunder, peneliti mengumpulkan data melalui beberapa referensi khususnya buku-buku, jurnal terkait humas pemerintah, human relations, melalui internet, dan lain-lain. Kemudian peneliti menggunakan observasi karena dari observasi yang dilakukan, peneliti dapat memperoleh pengamatan langsung dan melihat hal-hal yang tidak terungkap saat wawancara.

\section{HASIL DAN PEMBAHASAN}

Inti atau kunci dari pelaksanaan human relations menurut Ruslan (2016) dan Effendy (2009) adalah motivasi. Akan tetapi berdasarkan hasil temuan penelitian ini menunjukkan bahwa ada perbedaan pandangan humas Kemkominfo mengenai inti pelaksanaan human relations. Humas Kemkominfo mengatakan bahwa human relations dilakukan sebagai bentuk branding melalui penyampaian informasi dan interaksi untuk nantinya tercapai citra dan reputasi positif di mata masyarakat. Jadi inti pelaksanaannya adalah pada bagaimana segala penyampaian sesuatu kepada publik itu menjadi branding pemerintah.
Walaupun demikian pemikiran humas Kemkominfo sudah sesuai dengan pemikiran Ruslan (2016: 343) mengenai tugas dan fungsi humas pemerintah yang menjelaskan bahwa salah satu tugas pokok humas pemerintah yaitu menciptakan citra serta opini masyarakat yang positif dan fungsi humas pemerintah dalam memberikan pelayanan serta menyebarluaskan pesan atau informasi mengenai kebijakan hingga program kerja secara nasional kepada masyarakat.

Davis (1957: 4) juga mengemukakan mengenai tiga tujuan penting human relations yaitu untuk bekerjasama, menghasilkan, dan mendapat kepuasan dari pekerjaan mereka. Hal tersebut sesuai dengan temuan penelitian bahwa humas dan pegawai Biro Humas melakukan kerja sama satu sama lain dan juga kepada seluruh anggota Biro Humas. Temuan penelitian pun menunjukkan bahwa satu persatu pegawai sudah memiliki kepuasan kerja dan motivasi walaupun belum mencakup seluruh pegawai Biro Humas. Namun demikian, menilai dari adanya kerja sama, output dari pegawai dan kepuasan kerja, maka dapat dirumuskan bahwa tujuan human relations telah dicapai Biro Humas Kemkominfo.

Dalam menjalin hubungan baik di organisasi, ada beberapa prinsip-prinsip yang harus dipegang untuk mengembangkan human relations yang lebih baik. Prinsip-prinsip ini diambil dari prinsip Keith Davis (1957) yang membagi menjadi delapan prinsip yaitu kepentingan individu (importance of individual), saling menerima (mutual acceptance), kepentingan bersama (common interest), keterbukaan komunikasi (open communication), partisipasi pegawai (employee participations), identitas lokal (local identity), keputusan lokal (local decisions), dan standar moral yang tinggi (high moral standard).

1. Kepentingan Individu (Importance of Individual)

Human relations pada Biro Humas Kemkominfo telah memerhatikan kepentingan individu. Hasil temuan penelitian ini menunjukkan bahwa perhatian terhadap kepentingan individu dilakukan melalui pendekatan seperti pendekatan interpersonal. Pendekatan ini dilakukan ketika ada individu yang memiliki masalah sehingga terlihat adanya sikap dalam membantu pegawai lain.

Jika dikaitkan dengan konsep Davis (1957: 28) yang mengatakan bahwa setiap atasan sebaiknya mengetahui para pegawainya secara personal, hal itu juga terdapat pada hasil temuan. Temuan menunjukkan bahwa atasan di Biro Humas pada Subbagian Pengelolaan Opini Publik dan Analisa Berita mengetahui pegawainya secara personal. 
Pengetahuan atasan kepada pegawainya terlihat dari adanya pembagian tugas kerja yang diberikan kepada masing-masing pegawai sesuai dengan kemampuannya serta cara dia berkomunikasi dengan masing-masing pegawai.

Davis (1957: 28) juga mengatakan bahwa memastikan perlakuan masing-masing orang sebagai individu, pegawai, pekerja dan sebagainya juga penting dilakukan agar semangat kerja dapat meningkat dan kinerja juga dapat memuaskan. Jika dikaitkan dengan temuan penelitian didapat bahwa bentuk perlakuan masing-masing orang sebagai individu atau pegawai terlihat dari adanya perhatian yang diberikan pada pegawai lain melalui pemberian semangat dan lainnya. Adanya pemberian semangat tersebut diharapkan dapat meningkatkan semangat kerja dan juga kinerja pegawai lain.

Berbagai hal di atas adalah pembahasan dari sisi pegawai. Namun penelitian ini juga akan menganalisis dari sisi humas dalam melaksanakan human relations yang dikaitkan dengan prinsip human relations. Terkait dengan prinsip mengenai kepentingan individu, perhatian terhadap kepentingan masingmasing pegawai Biro Humas dilakukan oleh humas Kemkominfo dengan menampung segala pendapat, pandangan, aspirasi, keluhan dan lainnya melalui meeting internal. Lalu juga dibantu dengan pemberian pengarahan kepada pegawai Biro Humas ketika ada kesulitan dan membangun kemauan individu seperti yang telah disebutkan pada temuan penelitian. Berbagai hal itu dilakukan agar para pegawai dapat merasakan pekerjaannya. Hal ini seperti apa yang dikemukakan oleh Nooriza, selaku Plt Kepala Biro Humas Kemkominfo:

"Ya seperti yang sudah disampaikan. Kita tampung pendapat mereka, keluh resah, apa yang mereka inginkan, semuanya kita tampung. Kita kan ada meeting internal dan lain sebagainya." (Nooriza, Hasil Wawancara, 7 Juni 2017)

\section{Saling Menerima (Mutual Acceptance)}

Pada Biro Humas Kementerian Komunikasi dan Informatika dalam kegiatan human relations ditemukan bahwa masih ada beberapa pegawai yang tidak memiliki sikap saling menerima. Temuan penelitian menunjukkan tidak adanya sikap tersebut karena masih adanya keserakahan dari seseorang atau sekelompok orang di dalam organisasi untuk mendapat keuntungan pribadi. Keserakahan tersebut didapat dari adanya tingkat konsumsi pegawai tinggi yang tidak sesuai dengan penghasilan pegawai tersebut.
Davis (1957: 28) menjelaskan bahwa pegawai, serikat pekerja dan manajemen atau atasan perlu adanya sikap saling menerima sebagai individu dan kelompok. Akan tetapi temuan penelitian bertolak belakang dengan apa yang dikemukakan Davis. Temuan menunjukkan bahwa masih adanya kelompok-kelompok tertentu pada Biro Humas yang dibangun atau dibentuk karena adanya satu tujuan, keinginan, dan kebutuhan yang nantinya segala sesuatu selalu berputar di lingkungan itu saja. Kelompok tersebut biasa disebut "Klik". Hal ini seperti apa yang disampaikan oleh Teguh Wahyono selaku Humas sekaligus Kepala Subbagian Pengelolaan Opini Publik dan Analisa Berita:

"Klik adalah suatu kelompok tertentu yang dibangun, yang nantinya segala sesuatu selalu berputar di lingkungan dia saja. Itu ada yang namanya Klik seperti itu. Terkadang Klik itu dibentuk oleh beberapa orang terutama yang merasa satu tujuan, satu keinginan, dan satu kebutuhan. Terkadang juga ada yang dibangun oleh pimpinan. Pimpinan itu membuat Klik untuk membentuk pagar atau benteng, jadi ketika adanya serangan pada pimpinan itu, Klik adalah bentengnya, pagarnya yang akan menahan atau bahkan membalas serangan tersebut." (Teguh, Hasil Wawancara, 9 Juni 2017)

Klik yang dapat dikatakan sebagai kelompok bersifat negatif memang tidak hanya ada di BiroHumas Kemkominfo. Hasil temuan penelitian menunjukkan bahwa Klik pasti ada di setiap organisasi. Adanya kelompok Klik tersebut juga seringkali menimbulkan konflik antar pegawai dan konflik akibat Klik juga terjadi pada Biro Humas Kemkominfo salah satunya masalah hubungan antar pegawai. Hal itulah yang menunjukkan bahwa ketika ada suatu kelompok di suatu organisasi, tidak selalu kelompok tersebut diterima oleh seluruh anggota organisasi. Terkadang kelompok-kelompok yang juga dapat dibangun oleh pimpinan justru menimbulkan berbagai konflik pegawai yang nantinya dapat menghambat kinerja pegawai dan keberhasilan organisasi.

Namun, perlakuan humas dalam menumbuhkan sikap saling menerima di antara pegawai Biro Humas terus dilakukan dengan membangun karakter dan motivasi agar ketika atasan membutuhkan pegawai tersebut, mereka dapat langsung mengerjakan dan melakukan sesuatu sesuai kebutuhan. Hal itu juga sebagai bentuk pemahaman kepada pimpinan dalam hal pembagian tugas sebagaimana dikemukakan Davis (1957: 28) bahwa memahami antara pimpinan 
dan bawahan juga diperlukan dalam melakukan berbagai tugas yang diberikan.

Pembangunan karakter dan motivasi oleh humas juga dilakukan karena melihat pada temuan penelitian bahwa sikap saling menerima masih belum dimiliki oleh sebagian pegawai Biro Humas akibat adanya berbagai kelompok seperti Klik di atas.

\section{Kepentingan Bersama (Common Interest)}

Pelaksanaan komunikasi organisasi melalui human relations pada para pegawai Biro Humas juga memerhatikan kepentingan bersama. Temuan penelitian menunjukkan bahwa karena di suatu organisasi terdapat sistem dan sistem itu saling berkaitan, kerja sama oleh seluruh komponen organisasi juga dibutuhkan sebagaimana dikatakan Davis (195: 28) bahwa pegawai, serikat pekerja dan manajemen saling terikat satu sama lain dari kepentingan bersama. Adanya keterikatan ini untuk terciptanya tujuan organisasi yang dilakukan secara bersama melalui kerja sama satu sama lain.

Merujuk pada perkataan Davis di atas, temuan penelitian juga menunjukkan bahwa kerja sama dijalin di Biro Humas. Kerja sama yang dilakukan biasanya dalam bekerja karena seringkali suatu pekerjaan yang diberikan oleh atasan melebihi dari kapasitas kemampuan individu. Untuk itu kerja sama pun dilakukan melalui pembagian kerja dengan pegawai lain agar pekerjaan yang ditugaskan dapat segera terselesaikan.

Di samping kerja sama, kebersamaan pun dijalin pada seluruh pegawai Biro Humas. Kebersamaan pada Biro Humas tersebut karena adanya kesadaran bahwa kebersamaan dapat memperkuat dan memperkokoh dalam melaksanakan suatu kegiatan. Koordinasi pun tak lupa dilakukan oleh pegawai Biro Humas dalam melaksanakan pekerjaan.

Adanya koordinasi ini agar kesalahan dalam bekerja dapat diminimalisir dan hasil yang didapat berkualitas. Selain itu, tujuan humas Kemkominfo pun dapat tercapai sebagaimana pemikiran Komarudin (2014: 13) bahwa tujuan humas pemerintah menciptakan Sumber Daya Manusia (SDM) berkualitas, komunikatif, dan aspiratif yang dapat dilakukan melalui dibinanya hubungan baik dengan publik internal dan eksternal serta koordinasi baik secara vertikal maupun horisontal dengan komponen dalam organisasi.

Hasil temuan penelitian juga menunjukkan bahwa P.O.A.C. yaitu Planning, Organizing, Actuating dan Controlling juga dilakukan pada pegawai Biro Humas. P.O.A.C yang dapat dikatakan sebagai perencanaan kerja ini perlu diterapkan agar segala pekerjaan yang dilakukan lebih terencana, terstruktur dan lebih matang sehingga hasil yang didapat juga bisa memuaskan. Adanya P.O.A.C juga agar tercapainya tujuan dan keberhasilan organisasi.

Analisis dari sisi humas juga dilakukan. Temuan penelitian menunjukkan bahwa humas Kemkominfo juga menyetujui pentingnya kerja sama kepada seluruh pegawai Biro Humas. Hal itu sebagaimana dikutip Indrawijaya (2010: 100) bahwa kerja sama sering dianggap sebagai tujuan dari suatu sistem organisasi. Oleh karena itu penanaman pemahaman kepada atasan dan bawahan di Biro Humas coba dilakukan humas sebagai tujuan dari sistem organisasi seperti yang disebutkan di atas.

\section{Keterbukaan Komunikasi (Open Communication)}

Keterbukaan komunikasi pada para pegawai Biro Humas Kemkominfo juga dilakukan melalui salah satunya diskusi baik yang sifatnya formal ataupun informal. Selain diskusi, komunikasi terbuka juga dapat dilakukan saat pekerjaan sedang dilakukan. Hasil temuan penelitian menunjukkan bahwa keterbukaan komunikasi yang ada di Biro Humas tersebut tergantung pada situasi dan kemauan dari atasan.

Jika situasi yang terjadi mengharuskan untuk dilakukan komunikasi secara terbuka seperti saat ada masalah pada pegawai dan membutuhkan penyelesaian, komunikasi terbuka dapat dilakukan oleh pegawai tersebut kepada pegawai lain atau dengan atasan secara interpersonal. Hal tersebut juga didukung oleh pemikiran Ida Nurhaida \& Cahyono Eko (2006) dalam penelitiannya yang mengatakan bahwa human relations banyak melibatkan komunikasi antarpribadi dan salah satu bentuk pentingnya yaitu komunikasi terbuka.

Davis (195: 28) menjelaskan bahwa berbagi gagasan, informasi dan perasaan dengan seluruh komponen organisasi sangat penting sebagai jalan menuju pemahaman dan keputusan yang lebih baik. Penjelasan Davis jika dikaitkan dengan temuan penelitian ini menunjukkan bahwa berbagi perasaan juga dilakukan pada Biro Humas misal ketika adanya masalah yang menimpa pegawai, pegawai akan berbagi perasaannya kepada atasan. Selain itu berbagi gagasan juga dilakukan terutama ketika adanya perbedaan pandangan dan pemahaman antar satu pegawai dengan pegawai lain atau dengan atasan (pimpinan).

Lalu jika tergantung pada kemauan atasan misal atasan membutuhkan kreativitas pegawainya 
untuk hasil pekerjaan yang maksimal, komunikasi pun dapat dilakukan secara terbuka antara atasan dengan pegawainya. Pemberian tantangan kepada pegawai sebagai bentuk kesempatan untuk dapat menciptakan suatu penemuan dan mengembangkan kreativitas juga dilakukan melalui komunikasi terbuka.

Berbagai bentuk keterbukaan komunikasi di atas memang perlu dilakukan Biro Humas agar tidak terjadinya konflik seperti yang dikemukakan David (1957: 229) yaitu ketika komunikasi terbuka tidak dilakukan, maka hasilnya dapat meliputi kesalahpahaman, kurangnya motivasi, ketidakamanan, konflik, dan ketidakmampuan membuat keputusan yang efektif.

Pada sisi humas, temuan penelitian ini menunjukkan bahwa berbagi gagasan, informasi dan lainnya kurang terlihat sebagai sikap humas sebagai bentuk keterbukaan komunikasi. Mengacu pada temuan, hal tersebut dikarenakan humas Kemkominfo tidak selalu ada di tempat karena banyaknya acara kehumasan di luar Kemkominfo. Inilah yang dapat menjadi poin penting bahwa perhatian harus diberikan humas tidak hanya pada publik eksternal Kemkominfo tetapi juga publik internal.

Kurangnya keterbukaan komunikasi juga dapat menimbulkan konflik antar pegawai. Jika konflik itu tidak segera diselesaikan dapat berakibat buruk bagi pegawai atau bahkan organisasi. Akan tetapi sikap humas dalam menangani konflik yang terjadi juga masih dianggap kurang. Hal itu didapat dari temuan penelitian bahwa kurang adanya keseriusan dan kepedulian humas dalam menangani konflik pegawai Biro Humas.

Konflik dalam organisasi termasuk pada Biro Humas Kemkominfo memang sesuatu yang lazim terjadi. Jika konflik itu masih dalam skala yang tidak besar, tidak berkepanjangan dan bisa diselesaikan dengan musyawarah, hal itu bukan masalah besar. Namun jika konfliknya sudah meluas, konflik tersebut dapat memecah organisasi. Dengan demikian, penanganan yang tepat dari humas dibantu dengan kerja sama pegawainya inilah yang bisa menjadi salah satu cara menghindari kemungkinan timbulnya konflik.

\section{Partisipasi Pegawai (Employee Participations)}

Davis (1957: 28) mengemukakan bahwa partisipasi pegawai dilakukan dengan melibatkan partisipan dalam menyampaikan pendapat, ide, maupun saran bagi semua komponen dalam organisasi. Jika dikaitkan dengan temuan penelitian bahwa partisipasi pegawai juga dilakukan oleh pegawai Biro Humas Kemkominfo. Adanya partisipasi pegawai Biro Humas biasa dilakukan ketika adanya meeting internal. Temuan juga menunjukkan bahwa partisipasi pegawai Biro Humas dinilai sangat tinggi.

Hasil observasi penulis yang menunjukkan bahwa Viska salah seorang pegawai Biro Humas bersama satu pegawai Biro Humas lain berinteraksi dengan peneliti dan teman peneliti untuk meminta bantuan agar mau difoto untuk kebutuhan dokumentasi Diskominfo Malang. Viska pun ikut berpartisipasi demi pemenuhan kebutuhan dokumentasi untuk Diskominfo Malang. Adanya partisipasi yang dilakukan tersebut karena menyadari akan pekerjaannya dan pentingnya pemenuhan kebutuhan organisasi. Selain itu juga dikarenakan adanya rasa senang terhadap pekerjaannya.

Davis (1957: 28) juga mengemukakan bahwa hasil yang lebih baik dapat terjadi melalui adanya sikap saling berbagi serta pemecahan masalah dari orang-orang yang terpengaruh. Jika didapat dari temuan penelitian ini juga menunjukkan bahwa ada pemecahan masalah yang dilakukan pada Biro Humas. Pemecahan masalah terlihat dari adanya peran humas dan atasan dalam membantu jika ada pegawainya yang memiliki masalah. Pemecahan masalah tersebut juga biasanya dilakukan secara interpersonal.

Mengenai partisipasi pegawai, Davis (1972: 136) menambahkan bahwa partisipasi juga terjadi ketika pegawai diberi kesempatan untuk berinisiatif dan mengembangkan kreativitas mereka sendiri untuk mencapai tujuan organisasi. Hal itu yang kemudian coba ditekankan pada atasan di Biro Humas agar pegawainya memiliki kesadaran akan pekerjaannya, bertanggung jawab, mampu insiatif, dan mampu mengembangkan kreativitasnya.

Mengenai partisipasi pegawai, didapat dari temuan penelitian bahwa pemberian reward juga dilakukan humas kepada pegawai yang telah berpartisipasi dalam rangka menunjang peningkatan kinerja dan pencapaian tujuan organisasi. Pemberian reward ini juga terkait dengan penelitian Ida Nurhaida \& Cahyono Eko (2006) yang mengemukakan bahwa human relations juga memiliki dua bentuk penting yaitu komunikasi terbuka dan penghargaan dari pimpinan. Hal itu yang kemudian juga dilakukan pada Biro Humas untuk meningkatkan kesadaran, inisiatif maupun motivasi pegawai agar mau berpartisipasi. 


\section{Identitas Lokal (Local Identity)}

Davis (1957: 29) mengatakan bahwa individu dapat menerima kesempatan terbesar untuk pengakuan, kebanggaan dan kepuasan kerja melalui identifikasi dengan unit kerja lokalnya. Identifikasi juga dilakukan selama penelitian lapangan dan hasil menunjukkan bahwa pegawai Biro Humas juga dapat menerima kesempatan terbesar untuk kepuasan kerja. Namun kepuasan tersebut bisa didapat ketika pegawai mampu melakukan pekerjaan sesuai dengan S.O.P maupun target yang telah ditentukan oleh pimpinan. Kepuasan dalam hal ini tidak hanya dari pihak bawahan atau pegawai tetapi juga dari pihak atasan atau pimpinan.

Memperhatikan kepuasan kedua belah pihak juga dikarenakan dalam unit kerja tidak hanya terdiri dari pegawai, tetapi juga pimpinan maupun manajemen. Selain itu, humas pun berperan sebagai satuan dari unit kerja pada Biro Humas. Oleh karena itu, identifikasi kepada seluruh komponen Biro Humas diperlukan untuk melihat juga pada kepuasan masing-masing individu berdasarkan sikap yang dimilikinya, sebagaimana dikemukakan Robbins (2006: 32) bahwa kepuasan kerja lebih mencerminkan sikap daripada perilaku dan dapat dianggap sebagai tujuan resmi organisasi.

Temuan penelitian juga mengatakan bahwa humas melihat satu persatu pegawai Biro Humas sudah memiliki kepuasan. Berdasarkan dari adanya kepuasan pegawai tersebut dapat dirumuskan bahwa para pegawai Biro Humas memang sudah diberikan kesempatan untuk dapat pengakuan maupun kepuasan kerja.

\section{Keputusan Lokal (Local Decisions)}

Prinsip ketujuh dari Keith Davis juga diperhatikan oleh Biro Humas Kemkominfo dalam kegiatan human relations. Dikatakan oleh Davis (1957: 29) bahwa orang-orang yang paling dekat dengan masalah yang memengaruhi diri mereka sendiri dapat mengembangkan solusi yang paling memuaskan jika diberi wewenang untuk menyelesaikan masalah tersebut.

Mengacu pada perkataan Davis di atas, jika dilihat dari temuan penelitian ini menunjukkan bahwa pemberian wewenang diberikan kepada masing-masing pegawai jika ada masalah yang terjadi pada pegawai bersangkutan sehingga mereka dapat menyelesaikannya secara pribadi. Namun melihat pula bahwa adanya humas yang dapat berperan sebagai fasilitator komunikasi, penyelesaian masalah melalui pemberian solusi dari humas juga bisa dilakukan dengan pendekatan interpersonal kepada orang yang bersangkutan.

Tidak hanya humas, atasan pun dapat membantu dalam penyelesaian masalah yang terjadi pada pegawai. Berdasarkan hasil temuan penelitian dikatakan bahwa dalam Biro Humas, ada masingmasing bagian kerja. Pada masing-masing bagian tersebut ada tim yang terbentuk. Ketika dalam tim tersebut anggotanya mengalami masalah, tentu pemecahan masalah secara bersama dibutuhkan dan atasan pun juga ikut berperan serta.

Peran serta atasan ini bisa menjadi dasar dalam mengambil keputusan ketika permasalahan telah diketahui melalui pemberian solusi-solusi atau saran dan sebagainya. Namun tidak hanya atasan, peran humas terkait prinsip ini juga melihat pada cara humas membantu menyelesaikan masalah pegawainya yang biasanya dilakukan melalui tatap muka atau saat dilakukannya meeting internal.

\section{Standar Moral yang Tinggi (High Moral Standard)}

Human relations yang dilakukan pada Biro Humas juga memerhatikan pada standar moral yang tinggi. Perhatian pada standar moral itu karena mengacu pada konsep Davis (1957: 29) yang menyatakan ada beberapa kesepakatan mengenai area di mana kepuasan pegawai diperlukan agar memiliki moral yang tinggi. Area itu terdiri atas kecukupan pengawasan langsung, kepuasan dengan pekerjaan itu sendiri dan lain sebagainya.

Atas dasar itulah maka kepuasan pegawai Biro Humas diperhatikan baik oleh atasan maupun humas dalam kegiatan human relations. Jika dikaitkan dengan hasil temuan penelitian menunjukkan bahwa pengawasan langsung sering dilakukan oleh pimpinan pada Biro Humas pada pegawainya ketika melakukan pekerjaan. Pengawasan langsung tersebut dilakukan untuk menghindari adanya kesalahankesalahan selama proses bekerja. Temuan penelitian juga mengatakan bahwa ketika pegawai mampu bersikap profesional dan mampu bekerjasama, pegawai tersebut dikatakan memiliki moral yang tinggi. Hal itu sebagaimana yang dikatakan Davis (1957: 29) bahwa para profesional, pimpinan dan pekerja dengan moral tinggi menyukai pekerjaan dan organisasi mereka dan berkeinginan untuk bekerja sama dengan pegawai lain untuk pencapaian tujuan bersama. Moral yang tinggi juga merupakan ciri khas human relations yang baik dalam organisasi.

Moral dalam hal ini dapat disebut sebagai etika dalam bekerja di organisasi. Namun jika mengacu pada etika maupun moral, pada kenyataannya tidak 
menutup kemungkinan bahwa moral seseorang ketika dalam organisasi dan di luar organisasi tidak berubah. Ada sebagian orang yang berbeda baik dari etika maupun moral ketika sedang tidak bekerja walaupun sebagian lainnya mungkin sama. Akan tetapi hal inilah yang menjadi poin penting bahwa moral seseorang tidak dapat diukur hanya dari kepuasan yang dimiliki seperti yang dikatakan oleh informan penelitian.

\section{SIMPULAN}

Berdasarkan hasil analisis prinsip-prinsip human relations pada Biro Humas Kemkominfo dalam pelaksanaan komunikasi organisasi ditemukan bahwa Biro Humas Kemkominfo sudah melaksanakan tujuh dari delapan prinsip human relations yang ada. Satu prinsip yang belum dilaksanakan pada Biro Humas yaitu prinsip saling menerima (mutual acceptance) karena dari hasil temuan penelitian menunjukkan bahwa masih adanya kelompok-kelompok tertentu pada Biro Humas yang biasa disebut "Klik". Kelompok "Klik" dianggap sebagai kelompok yang bersifat negatif sehingga dari adanya kelompok tersebut terkadang menimbulkan konflik antar-pegawai Biro Humas salah satunya konflik hubungan antar satu pegawai dengan pegawai lain.

Adanya humas dalam melaksanakan human relations jika dikaitkan dengan prinsip-prinsip human relations yang ada, humas belum melaksanakan prinsip keterbukaan dalam komunikasi karena fokus perhatian humas cenderung kepada publik eksternal Kemkominfo. Lalu juga didapat dari masih kurangnya sikap keseriusan dan kepedulian humas ketika ada konflik pegawai akibat kurang atau tidak adanya keterbukaan komunikasi. Namun demikian mengacu pada tugas dan fungsi humas pemerintah, apa yang dilakukan humas Kemkominfo dalam melaksanakan human relations sudah sesuai dengan tugas dan fungsi yang ada. Walaupun tidak semua dari tugas dan fungsi yang ada dilakukan humas Kemkominfo, namun dapat disimpulkan bahwa humas Kemkominfo sudah melaksanakan tugas dan fungsinya dengan baik. Selanjutnya, pelaksanaan komunikasi organisasi yang di dalamnya ada komunikasi sebagai langkah utama membangun human relation juga sudah terjadi pada Biro Humas di mana komunikasi organisasi yang paling sering dilakukan yaitu komunikasi horisontal. Walaupun komunikasi ke atas dan ke bawah juga dilakukan namun intensitasnya tidak sebanyak komunikasi horisontal yang terjadi pada Biro Humas.

\section{DAFTAR PUSTAKA}

Ardianto, E. (2013). Handbook of Public Relations: Pengantar Komprehensif. Bandung: Simbiosa Rekatama Media.

Chung, K. H., \& Megginson, L. C. (1981). Organizational Behaviour: Developing Managerial Skill. United States: Harper \& Row Publishers.

Cutlip, et al. (2006). Effective Public Relations. Edisi Kesembilan. Jakarta: Kencana Prenada Media Group.

Davis, K. (1957). Human Relations in Business. United States: McGraw-Hill Inc.

(1972). Human behaviour at Work: Human Relations and Organizational Behaviour. (Fourth Edition). United States: McGraw-Hill.inc.

Davis, K., \& Scott, W. G. (1959). Reading in Human Relations. United States: McGraw-Hill Inc.

Effendy, O. U. (2009). Human Relations \& Public Relations. Bandung: CV. Mandar Maju.

Hidayat, D. (2014). Media Public Relations: Pendekatan Studi Kasus Cyber Public Relations Sebagai Metode Kerja PR Digital. Yogayakarta: Graha Ilmu.

Indrawijaya, A. I. (2010). Teori, Perilaku dan Budaya Organisasi. Bandung: PT Refika Aditama.

Keyton, J. (2005). Communication and Organizational Culture. United States: Sage Publications Inc.

Komarudin. (2014). Reformasi Humas Pemerintah. Jakarta: Penerbit Genesindo.

Lamberton, L., \& Evans, L. M. (2014). Human Relations: Strategies for Success (Business Careers. (5th Edition). United States: McGrawHill Inc.

Lengkey, L., Himpong, M. D., \& Norma, N. M., (2015). Peranan Human Relations Terhadap Motivasi Kerja Pegawai di Badan Kepegawaian Daerah (BKD) Provinsi Sulawesi Utara. E-journal Acta Diurna. Vol 4(3).

Miller, K. (2012). Organizational Communication: Approach and Processes, AISE. (Sixth Edition). United States: Wadsworth Cengage Learning.

Muhammad, A. (2008). Komunikasi Organisasi. Jakarta: Bumi Aksara.

Neuman, L. W. (2013). Metode Penelitian Sosial, Pendekatan Kualitatif dan Kuantitatif. Jakarta: PT Indeks.

Nurdin, R. A. (2009). Pengaruh Employee Relations dan Human Relations pada Motivasi Kerja (Studi 
Pada Karyawan PT Asuransi Ekspor Indonesia, Cabang Jakarta). Skripsi tidak diterbitkan. Universitas Indonesia.

Nurhaida, I., \& Cahyono, E. S. (2006). Komunikasi Secara Terbuka, Penghargaan Pimpinan dan Partisipasi Pegawai: Penerapan Human Relations dalam Kaitannya dengan Kinerja Pegawai. Jurnal Sosiohumaniora. Vol 8(1).

Quick, J. C. \& Nelson, D. L. (2013). Principles of Organizational Behaviour: Realities and Challenges. (Eighth International Edition). United States: Cengage Learning.

Raelin, J. A. (2002). Personal Career Development for Professionals. United States: Beard Books.

Reece, B. L., et.,al. (2011). Effective Human Relations: Interpersonal and Oranizational Applications. (Eleventh Edition). United States: Cengage Learning.

Ruben, B. D., \& Stewart, L. P. (2006). Communication and Human Behavior. Boston: Pearson Education, Inc.

Rumanti, M. A. (2005). Dasar-Dasar Public Relations: Teori dan Praktik. Jakarta: PT Grasindo.

Ruslan, R. (2016). Manajemen Public Relations dan Media Komunikasi: Konsepsi dan Aplikasi. (Edisi Revisi Cetakan 13). Jakarta: Rajawali Pers.

Robbins, S. P. (2006). Organizational Behaviour. (Edisi Bahasa Indonesia). Jakarta: PT Indeks Kelompok Gramedia. 